DOI: $10.31866 / 2410-1915.21 .2020 .208236$

UDC 719:7.021.2]:027.7

\title{
ACTIVITIES OF THE INNOVATIVE PROJECT “TREASURES OF THE NATION" BY THE SCIENTIFIC LIBRARY OF THE KYIV NATIONAL UNIVERSITY OF CULTURE AND ARTS
}

\author{
Alla Havryliuk ${ }^{1 a}$, Larysa Rybka ${ }^{2 a}$, Olena Skachenko ${ }^{3 a}$ \\ ${ }^{1} \mathrm{PhD}$ in State Management, Associate Professor, \\ ORCID:0000-0003-2743-0409, etnosvit24@ukr.net, \\ ${ }^{2}$ Deputy Director of Scientific Library, \\ ORCID: 0000-0003-1480-4037,rybka.larisa@ukr.net, \\ ${ }^{3}$ Head of Sector of Scientific Library, \\ ORCID:0000-0003-3827-5985, skachenko.nana@gmail.com, \\ ${ }^{a}$ Kyiv National University of Culture and Arts, \\ 36, Ye. Konovaltsia St., Kyiv, 01133, Ukraine
}

\section{For citations:}

Havryliuk, A., Rybka, L., \& Skachenko, O. (2020). Activities of the Innovative Project "Treasures of the Nation" by the Scientific Library of the Kyiv National University of Culture and Arts. Culture and Arts in the Modern World, 21, 54-68. https://doi.org/10.31866/2410-1915.21.2020.208236.

The purpose of the article is to provide review and analysis of the results of the innovative arts and cultural project "Treasures of the Nation" by the Scientific Library of the Kyiv National University of Culture and Arts. The project is to popularize the intangible cultural heritage of Ukraine, already protected by UNESCO and promoted to the Representative List. The research methodology involves the use of a historical and analytical approach to collect and analyse primary data; the content analysis of purposes, objectives and results; prognostic method to summarise and conceptualise the significance and role of the project in the study and facilitation of the intangible cultural heritage of Ukraine. The scientific novelty consists in keeping students and experts, who research the intangible cultural heritage, informed on the Scientific Library experience in implementing the "Convention for the Safeguarding of the Intangible Cultural Heritage"; about the structure of the e-resource "Intangible Cultural Heritage of Ukraine", its information and bibliographic content. Conclusions. The project objectives and activities during 2014-2019 are considered. The backgrounds for the implementation of the project and its purposes are highlighted, the main one is the popularization of Ukrainian elements included by UNESCO in the Representative List of the Intangible Cultural Heritage of Humanity. The main attention in the article is focused on the results through three parallel activities: informational, bibliographic, and educational. The role of the project in the development of communication between scientific institutions of different countries involved in the preservation of cultural heritage is disclosed. We are talking about the joint organization of the International Research-to-Practice Conference-

(C) Alla Havryliuk, 2020

(C) Larysa Rybka, 2020

(C) Olena Skachenko, 2020

The article was received by the editorial office: 29.01 .2020 
Festival "Intangible Cultural Heritage of Ukraine as a Modern Tourism Resource: Experience, Practice, Innovation" by the Faculty of Tourism, Hotel and Restaurant Business of the Kyiv National University of Culture and Arts and the Scientific Library. The main objectives of the conference is a comprehensive scientific review of the current state of the elements of the intangible cultural heritage as a national tourist resource in Ukraine and foreign countries.

Keywords: the intangible cultural heritage of Ukraine; UNESCO; university library; higher education.

\section{Introduction}

In the modern world, the influence of the sphere of culture on the development of society is obvious. Many bearers of cultural practice - places of historical and memorial interest, monuments, traditions, contemporary art - enrich our lives in many ways (UNESCO, 2016). The UNESCO conventions in the field of culture provide the world with a single form of the international cooperation; make up an integrated cultural management system; protect and preserve museum collections, world-wide natural, cultural, intangible, underwater heritage, and oral traditions. They also encourage innovation, creativity, the development of creative cultural spaces.

The Kyiv National University of Culture and Arts is one of the leading universities in Ukraine, where bachelor's and master's degrees in the fields of culture, arts, social communications, hotel and restaurant and tourism business can be earned. The scientific library is an important scientific, informational, cultural and educational centre of the University that provides effective support for the scientific, educational, and pedagogic processes, contributing to the improvement of the image and status of the University in the international market of the educational services.

The updating of the Intangible Cultural Heritage study at the University is the result of public demand for the evolution of the modern knowledge system among future specialists for the fields of culture, arts, and services.

At the time of the project start (April 2014), there were no similar innovative forms of popularisation of the intangible cultural heritage in Ukraine, including those initiated by library institutions. Therefore, the scientific library of Kyiv National University of Culture and Arts has set among its priorities the goal of development of an e-resource where, using modern computer technologies, information about national elements of the intangible cultural heritage is collected, systematised and promoted for both Ukrainian and foreign scientists.

The intangible cultural heritage is the subject of scientific research since the moment when in 2008 the Verkhovna Rada of Ukraine voted to join the UNESCO Convention for the Safeguarding of the Intangible Cultural Heritage. The study of various aspects of the identification and protection of the intangible cultural heritage has become the subject of study by foreign and Ukrainian scientists, including Z. Bosyk (2015), O. Dutchak (2017), L. Snehyrova, V. Teleutsa, A. Havryliuk (2019), S. Kowalska (2017) etc. The history, religious motifs and typology of folk ceramics of the Hutsul region are the subject of research by R. Baran, H. Ivashkiv, A. Kolupaieva, and A. Slobodian. The issues of 
preserving Kosiv painting ceramics as a unique phenomenon of Ukrainian art and culture of the Hutsul region are considered in the article by M. Hryniuk and N. Chornyi (2019).

Especially interesting and useful for the understanding of the foreign forms of protection of the intangible cultural heritage in the context of the cultural policy of Ukraine are the examples and conclusions of Z. Bosyk and A. Semeni$\mathrm{uk}(2015)$ that there is a positive dynamics of cooperation between educational institutions and museums on the subject of traditional crafts in order to actualise the study of the intangible cultural heritage among modern youth.

The study of the peculiarities of using the project approach in the development of the sphere of culture and art; solution of the problems of the formation of electronic collections are in Ukrainian and foreign scientists' limelight: I. Vynogradova, N. Davydova, H. Kovalchuk, L. Konoval, B. Kost, E. Lobuzina, O. Maryina, H. A. Pyskorska etc. At the same time, questions related to the study of the experience of libraries in the implementation of the educational and artistic projects to popularise the intangible cultural heritage of Ukraine remain scantily explored. The necessity to understand further ways of development of projects and programs of protection of the intangible cultural heritage is involved with the active participation of various cultural institutions of the country and institutions of higher education in the promotion of the intangible cultural heritage. The study of the experience of the Scientific Library of Kyiv National University of Culture and Arts in the development and implementation of the Treasures of the Nation project will help to educate a wide public and facilitate the scientific research.

\section{Purpose of the article}

The purpose of the article is to describe, analyse and generalise the results of the cultural and artistic, educational project "Treasures of the Nation", which objectives are to make popular the elements of the intangible cultural heritage of Ukraine, already protected by UNESCO and promoted to the Representative List of this organisation.

The purposes of the article have determined the use of the following methods: historical and analytical - for collection and analysis of primary data; content analysis of goals, premises and tasks; statistical - to assess the dynamics of development and the effectiveness of the project; prognostic - to summarise the results, comprehend the significance and role of the project in the popularisation of the intangible cultural heritage of Ukraine.

\section{Main research material}

\section{Background and scope of the project}

Each region of Ukraine has authentic features and cultural traditions, the study of which contributes to the identification and inclusion of the selected elements into local lists and further to the National List of Intangible Cultural Heritage. The study of the intangible cultural heritage of Ukraine is relevant and requires the attention of scientists, craftsmen and bearers of traditions, 
and libraries as information centres. Taking into account the relevance of $\mathrm{Ar}$ ticle 14 - Education, awareness-raising and capacity-building of the Convention for the Safeguarding of the Intangible Cultural Heritage (hereinafter - the Convention), adopted on October 17, 2003, by the General Conference of the United Nations Educational, Scientific and Cultural Organization (hereinafter UNESCO), namely: "Each State Party shall endeavour, by all appropriate means, to ensure recognition of, respect for, and enhancement of the intangible cultural heritage in society, in particular through:

- educational, awareness-raising and information programmes, aimed at the general public, in particular young people;

- specific educational and training programmes within the communities and groups concerned;

- capacity-building activities for the safeguarding of the intangible cultural heritage, in particular management and scientific research;

- non-formal means of transmitting knowledge (UNESCO, 2003), in April 2014, the library of Kyiv National University of Culture and Arts initiated the innovative project "Treasures of the Nation" at that time.

Among the important backgrounds for the launch of the project, we can name:

- the relevance of the study of the intangible cultural heritage of Ukraine;

- the possibility of implementation of the project in the educational and communication space of the university, one of the largest centres for the training of specialists in culture and art in Ukraine;

- a wide target audience - teachers and students of the departments which require knowledge on this topic in their educational and scientific activities (Skachenko, 2016b).

The main objects of the project:

- familiarization with UNESCO's cultural conventions, international cultural cooperation between Ukraine and UNESCO, objects of Ukrainian historical and cultural, natural and intangible heritage;

- the University students and teachers' attention drawing to the intangible cultural heritage of Ukraine; information support for subject matter research;

- rising the level of knowledge to ensure respect for the heritage;

- communication with masters and bearers of traditions and popularisation of Ukrainian elements of intangible cultural heritage, protected by UNESCO or promoted to the Representative List.

The partners of the project are the Library of Ukrainian Art by Ekaterina Lebedeva, Petrykiv Museum of Ethnography, Life and Applied Arts, Centre of Folk Art "Petrykivka", the charitable organization "Authentic Hutsulschyna Charity Fund", Krolevets Weaving Museum, the Faculty of Tourism, Hotel and Restaurant and Business of the Kyiv National University of Culture and Arts.

From the very beginning, the implementation of the goals was planned by such activities:

- informational: preparation and edition of popular science publications, informational materials;

- bibliographic: the formation of electronic information and bibliographic resource on the website of the library; 

artworks.

- popularisation: workshops, exhibitions and presentations of craftsmen'

In 2017, the education work of the project was updated.

Over the five years of the project (2014-2019), positive results were achieved. Informational activities

Five journals have been prepared over the years of the project implementation. (Fig. 1):

- the booklet “UNESCO World Heritage Sites in Ukraine” (Skachenko, 2014);

- the booklet "The objects of the UNESCO World Heritage in Ukraine" (Skachenko, 2015);

- the scientific publication "Kosiv hand-drawn ceramics as a phenomenon of Ukrainian culture” (Skachenko \& Hryniuk, 2017);

- the science publication "Petrykivka: Picturesque Wonderworld" (Skachenko, 2017).
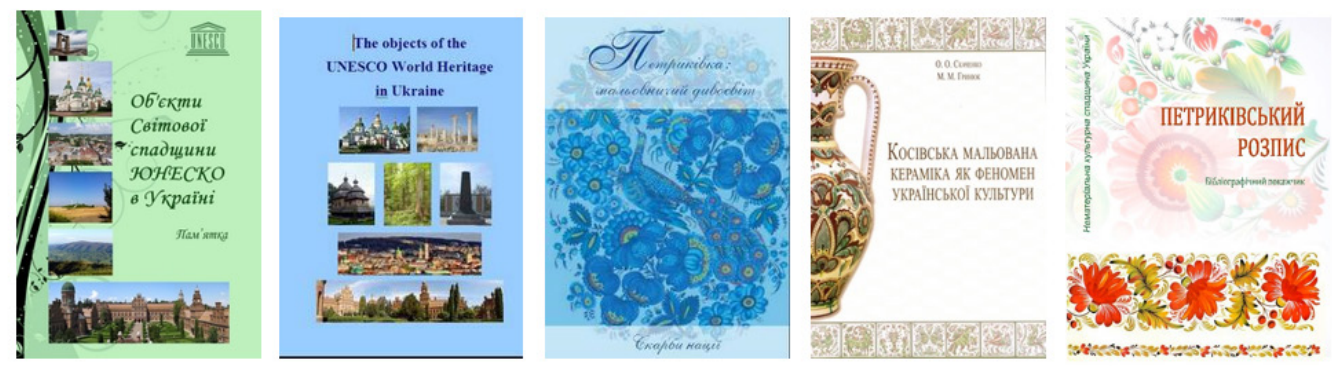

Figure 1. Information and bibliographic publications of the project

\section{Bibliographic activities}

The variety of information technologies, the popularisation of the intangible cultural heritage in the cultural and scientific community of Ukraine actualised the development of the bibliographic activities of the project. The bibliographic index "Petrykivka painting" (Steshenko \& Skachenko, 2018), published on the Calameo platform, contains description of 541 information sources (including webliography) that give an idea of Petrykivka painting Ukrainian decorative and ornamental art of the $19^{\text {th }}-21^{\text {st }}$ centuries, the first element of Ukraine in the UNESCO World Heritage List.

Since October 2015, the electronic information and bibliographic resource "Intangible Cultural Heritage of Ukraine" has been created on the website of the Scientific Library ("Intehrovanyi elektronnyi", 2015). At first, its structure corresponded to the national list of the intangible cultural heritage elements (in 2014 - 6 elements) and consisted of separate tabs for each element: "Petrykivka painting", "Kosiv painted ceramics", "Cossack songs of Dnipropetrovsk region", "Opishnia ceramics", "Krolevets woven towels". The last two elements are only promoted to the UNESCO Intangible Cultural Heritage Representative List.

Till January 2020, work on two parts of the resource has been completed: "Petrykivka painting" and "Kosiv painted ceramics" (Fig. 2). 


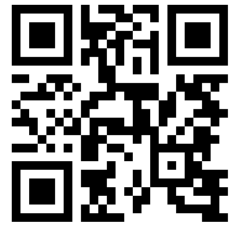

Figure 2. QR code to go to the project web page

The tab structure of these elements is identical and consists of four sections:

- Reference overview information of an element;

- Modern bearers of an element (includes brief biographical information and photographs of modern masters' works) (Fig. 3);

- Bibliography of individual publications about an element and catalogues/albums of masters' works (Fig.4);

- Bibliography of articles on an element in scientific publications and periodicals (Skachenko, 2016b, pp. 161-162).

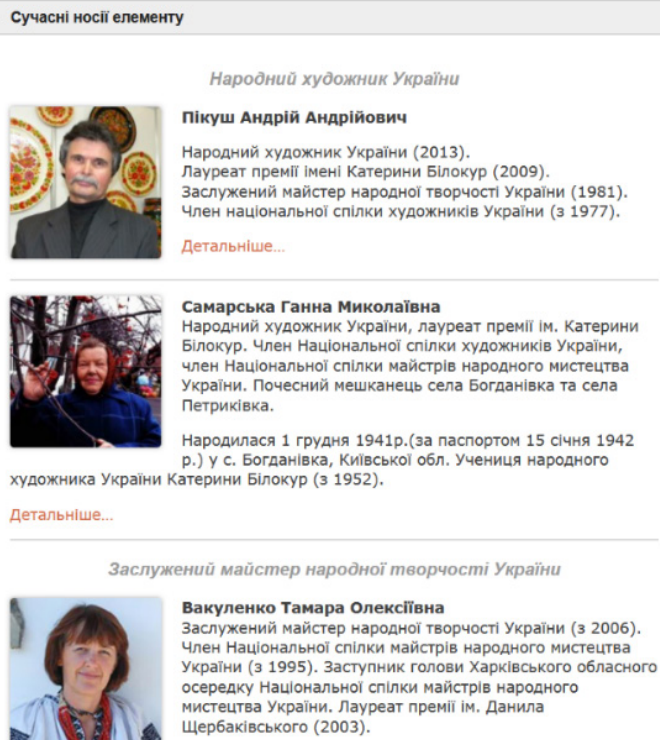

Пікуш Андрій Андрійович

Народний художник України (2013).

Лауреат премії імені Катерини Білокур (2009).

Заслужений майстер народної творчості України (1981).

Член національної спілки художників України (з 1977).

Детальніше.

Самарська Ганна Миколаївна

Народний художник України, лауреат преміі ім. Катерини

Білокур. Член Національної спілки художників Украіни,

член Національної спілки майстрів народного мистецтва

України. Почесний мешканець села Богданівка та села

Петриківка.

Народилася 1 грудня 1941р.(за паспортом 15 січня 1942

р.) у с. Богданівка, Київської обл. Учениця народного художника України Катерини Білокур (з 1952).

Детальніше...

Заслужений майстер народної творчості Украйни

Вакуленко Тамара Олексіївна

Заслужений майстер народної творчості України (з 2006).

Член Наніональної спілки майстрів народного мистентва

України (з 1995). Заступник голови Харківського обласного

осередку Національної спілки майстрів народного

мистеитва України. Лауреат премії ім. Данила

щербаківського (2003).

Figure 3. Web page “Modern Bearers of the Element”, screenshot

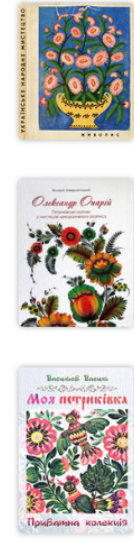

Бутник-Сіверський Б. Українське народне мистецтво.

Живопис / Б. Бутник-Сіверський, В. Нагай, В. Самойлович. - Київ

: Мистецтво, 1967. - Т. 4. - 224 с. (Завантажити)

Завершинський В. Олександр Опарій. Петриківські мотиви

у мистецтві декоративного розпису / Валерій Завершинський.

- Харків : Раритетиукраїни, 2017. - 168 с. : іл. - (Серія «Майстри

українського фарфору та фаянсу»).

Figure 4. Web page "Bibliography of individual publications regarding the element”, screenshot 
Since "Petrykivka Painting" was the only element of the intangible cultural heritage of Ukraine that has UNESCO status until December 2019, reference information and biographical information about contemporary masters are also presented in English. On December 12, 2019, at the $14^{\text {th }}$ session of the Intergovernmental Committee for the Intangible Cultural Heritage of UNESCO (Bogota, Colombia), Kosiv painted ceramics from Kosiv, Ivano-Frankivsk Region, was included into UNESCO Intangible Cultural Heritage List. The project partner and co-author of the scientific publication "Kosiv Painted Ceramics as a Phenomenon of Ukrainian Culture” Maryia Hryniuk, PhD of Art Studies, presented the element.

The tab "Krolevets woven towels" has three sections, there is no information about the contemporary craftsmen of weaving. The tab "Cossack songs of Dnepropetrovsk region" contains only reference information about the element included into UNESCO Intangible Cultural Heritage List that needs protection.

The unique result of the project "Treasures of the Nation" is the electronic informational and bibliographic resource "Intangible Cultural Heritage of Ukraine" that for the first time provided the systematic biographical information about contemporary craftsmen who cherish the features of each element and photographs of their works to all users who are interested in.

The total number of represented sources is 723, including 153 individual publications, 570 articles. The statistical information about the content of the resource is shown in table 1 .

The content metric of the e-resource

Table 1

\section{"Intangible Cultural Heritage of Ukraine"}

\begin{tabular}{|l|c|c|c|}
\hline & $\begin{array}{c}\text { Petrykivka } \\
\text { painting }\end{array}$ & $\begin{array}{c}\text { Kosiv painted } \\
\text { ceramics }\end{array}$ & $\begin{array}{c}\text { Krolevets } \\
\text { woven towels }\end{array}$ \\
\hline $\begin{array}{l}\text { The number of craftsmen' } \\
\text { biographies }\end{array}$ & 22 & 34 & 0 \\
\hline $\begin{array}{l}\text { The number of books, catalogues, } \\
\text { albums, dissertations / including } \\
\text { full-text publications }\end{array}$ & 76 & 57 & 20 \\
\hline $\begin{array}{l}\text { The number of articles in scientific } \\
\text { publications and periodicals, media }\end{array}$ & 297 & 149 & 124 \\
\hline
\end{tabular}

The relevance and necessity of the resource are confirmed by the statistics of viewing the web pages of the project. The data for 2015 are recorded for the period from October to December (Fig. 5).

The comparison of the data (in \%) of the unique page views and the viewing of the library's website for the period of 2016-2019 showed that the "Treasures of the Nation" project is in the TOP-5 pages of the most frequently visited during the specified period. The rate of the unique page views of the project is from 


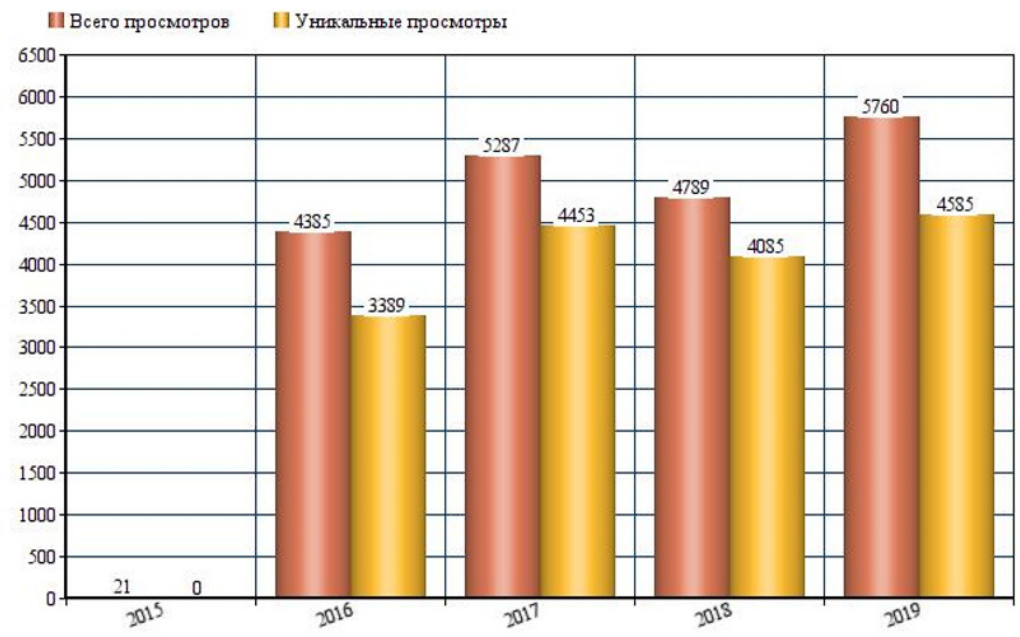

Figure 5. Dynamics of browsing the project web pages, 2015-2019

$11.47 \%$ in $2016 ; 16.74 \%$ in $2017 ; 13.75 \%$ in 2018 to $17.36 \%$ in 2019 . Good results are also shown by the indicator of the average time spent by users on the project pages: from 4:00 (minimum) to 5:46 minutes (maximum) with an average on the site of $1: 44$ minutes.

\section{Popularisation and communication activities}

Such forms of popularisation as exhibitions and presentations were the most interesting for students since they provided the opportunity for personal communication with the craftsmen who came to the university library to demonstrate the techniques of creation of their works. During the project, six exhibitions of works by the craftsmen of Kosiv painting, the lecture on "Folk crafts of Ukraine and unique centres for their development and popularisation" (2015), and painting workshops on Petrykivka painting $(2017,2018)$ were held.

Research assistance for the university's lecturers

The first results of the project, the statistics of requests at the web pages of the electronic resource, reviews of participants of exhibitions and presentations updated the issues of the necessity to implement the objectives of the project through research assistance. There were organised trips of the university library workers to folk craft development centres, national museums and historical and cultural reserves to organise contacts and further cooperation.

The library project coordinator Olena Skachenko presented books and content of the e-resource "Intangible Cultural Heritage of Ukraine" at the international scientific and practical conferences (Kyiv: 2015, 2016); the scientific seminar "On the issue of the Intangible Cultural Heritage" in the National Natural Park "Hutsulshchyna" (Kosiv, 2016). The experience of popularisation of the ethnographic elements and traditions was studied at the centre of folk art "Hutsulska Grazhda" in the village of Yavoriv, Ivano-Frankivsk region. Taking into account "the importance of cultural practices for safeguarding the intangible cultural heritage as a factor of the national heritage of past gen- 
erations that ensure diversity and are the guarantor of sustainable development" (Bosyk \& Semeniuk, 2015, p. 8), library staff visited the Open Festival of Ceramics, Crafts and Folklore "Malovanyi Dzbanyk" in Kosiv, studying the practical aspects of preserving Kosiv painted ceramics, visiting the workshops of the modern masters of ceramics, collecting biographical and photo materials for the scientific publication "Kosiv painted ceramics as a phenomenon of Ukrainian culture".

In 2017, the Faculty of International Tourism of the University opened the author's academic course on "Attractive Resources of the UNESCO Intangible Cultural Heritage" (the developer is Alla Havryliuk), and in 2018, the scientific and educational tourist cluster "Intangible Cultural Heritage as a Tourist Resource" was developed. To increase the self-education and involvement of students in the study of the intangible cultural heritage of Ukraine, the library staff prepared several electronic multimedia products (book trailers, presentations, longreads) within the framework of the project that tells about the Ukrainian elements of the intangible cultural heritage and the project "Treasures of the Nation". Taking into account the necessity of keeping the scientific community of Ukraine informed about the materials and resources of the project, the multimedia longread "Treasures of the Nation" was created on the Tilda Publishing online platform (“Treasures of the Nation”, 2017).

\section{Educational activities}

The closest and most fruitful cooperation within the framework of the project was established with the Faculty of Tourism, Hotel and Restaurant Business of the University: "the project helped to expand the range of practical component of acquaintance with etnoturistic resources of Ukraine and became an important educational component of the author's academic course "Ukrainian ethnic tourism" (Skachenko, 2016a).

The three-year creative cooperation got further development. The Faculty of International Tourism and the Scientific Library of the University put forward an idea and became co-organisers of the international scientific and practical conference-festival "Intangible Cultural Heritage of Ukraine as a Modern Tourism Resource: Experience, Practice, Innovation”. The main objective of the conference is a complex review of the current state of the elements of intangible cultural heritage as a national tourist resource in Ukraine and foreign countries. In 2019, the conference was held for the third time, bringing together representatives of national cultures from Armenia, Georgia, Belarus, Poland, the Slovak Republic, Hungary, and Ukraine.

The theme of the conference planned to implement the objectives of the scientific and educational tourism cluster "Intangible Cultural Heritage as a Tourism Resource", developed on the basis of the Kyiv National University of Culture and Arts and Kyiv University of Culture. The cluster "is evidence of the perfection of the technology for providing knowledge to future tourism experts the graduates of the speciality 242 "Tourism" of bachelor's, master's, PhD degrees in the framework of traditional and innovative practices for the formation of professional competencies" (Havryliuk, 2019, p. 51). The conference sessions "create the conditions for the use of innovative practices in order to disseminate 
knowledge about the intangible cultural heritage within the framework of the course study "Attractive resources of the UNESCO Intangible Cultural Heritage"; reveal "Living Tradition" of their distribution; conduct the scientific research working on <...> qualification papers" (Havryliuk, 2019, p. 51).

Striving for the widening of the project objectives and developing international cooperation, in 2017, there was a meeting of students and lecturers with scientists from the ethnographic museum of the city of Tarnów (the Republic of Poland), who presented at the University the exhibition of paintings "Painted Zalipie" about the unique village in the Lesser Poland Voivodeship, known for a century-old tradition of art painting of houses.

All events and forms of project activity were regularly covered on the websites of the library and the University; Ukrainian media. 4 articles about the tasks and intermediate results of the project were published in Ukrainian and foreign scientific journals, materials of international conferences.

\section{Conclusions}

The undertaken study revealed that the transformation of higher education identified new challenges for the work of university scientific libraries. Applying innovations, online tools and technologies, the Scientific Library of the Kyiv National University of Culture and Arts forms its own cultural and educational space: develops relevant projects, offers new information services.

The article describes the purposes and objectives of the innovative arts and cultural project "Treasures of the Nation", initiated by the Scientific Library in 2014. The results of project implementation activities are summarised: informational, bibliographic, educational, popularisation and communication. The analysis of the structure of the e-resource "Intangible Cultural Heritage of Ukraine”, its information content, effectiveness was made.

The role of the project in the development of cooperation between institutions of higher education and scientific institutions of different countries involved in the preservation of cultural heritage is revealed. In particular, the joint organisation of the International scientific and practical conferencefestival "Intangible Cultural Heritage of Ukraine as a Modern Tourism Resource: Experience, Practice, Innovation" by the Faculty of International Tourism of the Kyiv National University of Culture and Arts and the scientific library. The main objectives of which are a complex review of the current state of the elements of the intangible cultural heritage as a national tourist resource in Ukraine and foreign countries.

Realizing the objectives of the project "Treasures of the Nation", the Scientific Library of the Kyiv National University of Culture and Arts:

- forms the information space and digital base of sources for researching the intangible cultural heritage of Ukraine

- brings up patriotic feelings of pride, draws the attention of young people to Ukrainian traditions and customs

- actualises the popularisation of the intangible cultural heritage of Ukraine. 
The prospects for further researches include the analysis of digital resources created within the framework of the project to popularise the intangible cultural heritage of Ukraine.

\section{References}

Bosyk, Z. (2015). Nematerialna kulturna spadshchyna Ukrainy v konteksti suspilnoho rozvytku ta kulturnoi polityky derzhavy [The non-material cultural heritage of Ukraine in the context of social development and cultural policy of the country]. National Academy of Managerial Staff of Culture and Arts Herald, 2, 35-39. https:// doi.org/10.32461/2226-3209.2.2015.138378_[in Ukrainian].

Bosyk, Z. O., \& Semeniuk, A.V. (2015). Kulturni praktyky zarubizhnoho dosvidu z okhorony nematerialnoi kulturnoi spadshchyny v konteksti kulturnoi polityky Ukrainy [Cultural practices of foreign experience on the protection of the intangible cultural heritage in the context of Ukrainian cultural policy]. Topical problems of History, Theory and Practice of Artistic Culture, 34, 3-10 [in Ukrainian].

Dutchak, O. I. (2017). Nematerialna kulturna spadshchyna YuNESKO v Ukraini: perspektyvy vykorystannia $\mathrm{v}$ industrii turyzmu [UNESCO Intangible Cultural Heritage in Ukraine: Implementation Prospects in the Tourism Industry].Karpatskyi krai, 1, 165-170 [in Ukrainian].

Havryliuk, A. M. (2019). Scientific and educational tourism cluster of education and popularization of the intangible cultural heritage in Ukraine. The scientific heritage, 5(41), 49-51. https://cyberleninka.ru/article/n/scientific-and-educational-tourismcluster-of-education-and-popularization-of-intangible-cultural-heritage-inukraine [in Ukrainian].

Hryniuk, M. M., \& Chornyi, M. O. (2019). Sakralnyi obraz kosivskoi malovanoi keramiky [The sacral image of the Kosiv painted ceramics]. Bulletin of KNUKiM. Series in Arts, 41, 209-215. https://doi.org/10.31866/2410-1176.41.2019.188701 [in Ukrainian].

Intehrovanyi elektronnyi informatsiino-bibliohrafichnyi resurs "Nematerialna kulturna spadshchyna Ukrainy" [Integrated electronic information and bibliographic resource "Intangible Cultural Heritage of Ukraine"]. (2015). http://lib.knukim.edu.ua/proektibiblioteki/proekt-skarbi-nacii/ [in Ukrainian].

Kost, B., \& Piskorska, H. A. (2017). Kulturni proekty yak instrument zovnishnoi polityky [Cultural projects as a tool of foreign policy]. International relations. Series: Political Sciences, 15. http://journals.iir.kiev.ua/index.php/pol_n/article/view/3134 [in Ukrainian].

Kowalska, S. (2017). The Protection of the Ukrainian Cultural Heritage in UNESCO Programmes. Visnyk of Lviv national academy of Arts, 34, 192-201. https://doi. org/10.5281/zenodo.1170636 [in Ukrainian].

Skachenko, O. O. (Comp.). (2014). Obiekty Svitovoi spadshchyny UNESKO v Ukraini [UNESCO World Heritage Sites in Ukraine]. Vydavnychyi tsentr KNUKiM [in Ukrainian].

Skachenko, O. O. (Comp.). (2015). The objects of the UNESCO World Heritage in Ukraine. http://lib.knukim.edu.ua/wp-content/uploads/UNESSO_world_Heritage.pdf [in English]. 
Skachenko, E. A. (2016a). Zadachi proekta "Sokrovishcha natcii" v sisteme informatcionnogo soprovozhdeniia nauki i obrazovaniia [Objectives of the project "Treasures of the Nation" in the system of information support of science and education]. In Biblioteka kak fenomen kultury: Informatcionnye resursy bibliotek $v$ obrazovatelnoi, nauchnoi i sotciokulturnoi srede [Library as a cultural phenomenon: Information resources of libraries in the educational, scientific and sociocultural environment], Proceedings of the IV International Congress (pp. 72-77). National Library of Belarus [in Russian].

Skachenko, O. O. (2016b). Innovatsiino-osvitnii proekt "Skarby natsii" ta yoho realizatsiia u naukovii bibliotetsi KNUKiM [Innovation and Educational Project "Treasures of the Nation" and its implementation in the KNUKiM Scientific Library]. Odesa National University Herald. Library studies, Bibliography studies, Bibliology, 21(1), 158-166. https://doi.org/10.18524/2304-1447.2016.1(15).80551 [in Ukrainian].

Skachenko, O. O. (Comp.). (2017). Petrykivka: malovnychyi dyvosvit [Petrikivka: picturesque wonderworld]. http://lib.knukim.edu.ua/wp-content/uploads/2014/12/ Petrikivka-2017.pdf [in Ukrainian].

Skachenko, O. O., \& Hryniuk, M. M. (2017). Kosivska malovana keramika yak fenomen ukrainskoi kultury [Kosiv painted ceramics as a phenomenon of Ukrainian culture]. Vydavnychyi tsentr KNUKiM [in Ukrainian].

"Skarby natsii" ["Treasures of the Nation"]. (2017). [Multimedia]. http://skarbi-natsiyi. tilda.ws/ [in Ukrainian].

Steshenko, H. O., \& Skachenko, O. O. (2018). Petrykivskyi rozpys [Petrikiv painting]. Calameo. https://ru.calameo.com/read/0052879115ddef39adfe0 [in Ukrainian].

UNESCO. (2003). Konventciia ob okhrane nematerialnogo kulturnogo naslediia [Convention for the Safeguarding of the Intangible Cultural Heritage] https://www.un.org/ru/ documents/decl_conv/conventions/cultural_heritage_conv.shtml [in Russian].

UNESCO. (2016, November 04). Konferentciia osobo podcherknula vzaimodopolniaiushchuiu missiiu muzeev i obektov Vsemirnogo naslediia [The conference emphasized the complementary mission of museums and World Heritage sites]. UNESCO press. http://www.unesco.org/new/ru/media-services/ single-view/news/pervaja_mezhdunarodnaja_konferenci/ [in Russian]. 


\title{
ФОРМИ ДІЯЛЬНОСТІ ІННОВАЦІЙНОГО ПРОЕКТУ «СКАРБИ НАЦЇ̈» НАУКОВОЇ БІБЛІОТЕКИ КИЇВСЬКОГО НАЦІОНАЛЬНОГО УНІВЕРСИТЕТУ КУЛЬТУРИ І МИСТЕЦТВ
}

\author{
Гаврилюк Алла Михайлівна ${ }^{1 a}$, Рибка Лариса Анатоліївна ${ }^{2 a}$, \\ Скаченко Олена Олексіївна ${ }^{3 а}$
}
${ }_{1}^{1}$ Кандидат наук із державного управління, доцент, ORCID: 0000-0003-2743-0409, etnosvit24@ukr.net, 2Заступник директора наукової бібліотеки, ORCID: 0000-0003-1480-4037,rybka.larisa@ukr.net, зЗавідувачка сектором наукової бібліотеки, ORCID:0000-0003-3827-5985, skachenko.nana@gmail.com, ${ }^{a}$ Київський національний університет культури і мистецтв, Київ, Україна

Мета статті: характеристика, аналіз та узагальнення результатів інноваційного культурно-мистецького та просвітницького проекту «Скарби нації» наукової бібліотеки Київського національного університету культури і мистецтв. Проект присвячений популяризації елементів нематеріальної культурної спадщини України, які вже охороняються ЮНЕСКО і просуваються до Репрезентативного списку цієї організації. Методологія дослідження передбачає застосування історико-аналітичного методу для збору і аналізу первинних даних; контент-аналізу цілей, передумов і завдань; статистичного - для оцінки динаміки розвитку та ефективності електронного ресурсу; прогностичного - для узагальнення результатів, осмислення значення і ролі проекту в популяризації нематеріальної культурної спадщини України. Наукова новизна полягає в інформуванні студентів і фахівців, які досліджують нематеріальну культурну спадщину, про досвід наукової бібліотеки з реалізації положень «Конвенції про охорону нематеріальної культурної спадщини»; про структуру електронного ресурсу «Нематеріальна культурна спадщина України», його інформаційне і бібліографічне наповнення. Висновки. Розглянуто завдання і форми реалізації проекту, робота над яким велася упродовж 2014-2019 років. Виділено передумови реалізації проекту, його головна мета - популяризація українських елементів, включених ЮНЕСКО до Репрезентативного списку нематеріальної культурної спадщини людства. Основнуувагу в статті акцентовано на результатах роботи по чотирьох паралельних формах проекту: інформаційній, бібліографічній, популяризації та комунікації, освітній. Розкрито роль проекту в розвитку співпраці між закладами вищої освіти та науковими установами різних країн, що займаються питаннями збереження культурної спадщини. Зокрема, спільної організації кафедрою міжнародного туризму Київського національного університету культури і мистецтв та науковою бібліотекою Міжнародної науковопрактичної конференції-фестивалю «Нематеріальна культурна спадщина України як сучасний туристичний ресурс: досвід, практики, інновації». Головними завданнями якої $€$ комплексний огляд сучасного стану елементів нематеріальної культурної спадщини як національного туристичного ресурсу в Україні та зарубіжних країнах.

Ключові слова: нематеріальна культурна спадщина України; ЮНЕСКО; бібліотека університету; вища освіта. 


\title{
ФОРМЫ ДЕЯТЕЛЬНОСТИ ИННОВАЦИОННОГО ПРОЕКТА «СОКРОВИЩА НАЦИИ» НАУЧНОЙ БИБЛИОТЕКИ КИЕВСКОГО НАЦИОНАЛЬНОГО УНИВЕРСИТЕТА КУЛЬТУРЫ И ИСКУССТВ
}

\author{
Гаврилюк Алла Михайловна ${ }^{1 a}$, Рыбка Лариса Анатольевна ${ }^{2 a}$, \\ Скаченко Елена Алексеевна ${ }^{3 a}$
}

${ }^{1}$ Кандидат наук по государственному управлению, доцент, ORCID:0000-0003-2743-0409, etnosvit24@ukr.net, 2Заместитель директора научной библиотеки, ORCID: 0000-0003-1480-4037, rybka.larisa@ukr.net, зЗаведующая сектором научной библиотеки, ORCID:0000-0003-3827-5985,skachenko.nana@gmail.com, ${ }^{a}$ Киевский национальный университет культуры и искусств, Киев, Украина

Цель статьи: характеристика, анализ и обобщение результатов инновационного культурно-художественного и просветительского проекта «Сокровища нации» научной библиотеки Киевского национального университета культуры и искусств. Проект посвящен популяризации элементов нематериального культурного наследия Украины, уже охраняемых ЮНЕСКО и продвигающихся в Репрезентативный список этой организации. Методология исследования предполагает применение историкоаналитического метода для сбора и анализа первичных данных; контент-анализа целей, предпосылок и задач; статистического - для оценки динамики развития и эффективности проекта; прогностического - для обобщения результатов, осмысления значения и роли проекта в популяризации нематериального культурного наследия Украины. Научная новизна состоит в информировании студентов и специалистов, исследующих нематериальное культурное наследие, об опыте научной библиотеки по реализации положений «Конвенции об охране нематериального культурного наследия»; о структуре электронного ресурса «Нематериальное культурное наследие Украины», его информационном и библиографическом наполнении. Выводы. Рассмотрены задачи и формы реализации проекта, работа над которым велась в течение 2014-2019 годов. Выделены предпосылки реализации проекта, его главная цель - популяризация украинских элементов, включенных ЮНЕСКО в Репрезентативный список нематериального культурного наследия человечества. Основное внимание в статье акцентировано на результатах работы по четырем параллельным формам проекта: информационной, библиографической, популяризации и коммуникации, образовательной. Раскрыта роль проекта в развитии сотрудничества между высшими учебными заведениями и научными учреждениями разных стран, занимающихся вопросами сохранения культурного наследия. В частности, совместной организации кафедрой международного туризма Киевского национального университета культуры и искусств и научной библиотекой Международной научно-практической конференции-фестиваля «Нематериальное культурное наследие Украины как современный туристический ресурс: опыт, практики, инновации». Главными задачами которой является комплексный обзор современного состояния элементов нематериального 
ISSN 2410-1915 (Print) • Culture and Arts in the Modern World. Issue 21 • ISSN 2616-423X (Online)

культурного наследия как национального туристического ресурса в Украине и зарубежных странах.

Ключевые слова: нематериальное культурное наследие Украины; ЮНЕСКО; библиотека университета; высшее образование. 